\title{
JOHN MITCHELL KEMBLE'S ANGLO-GERMANIC LEGAL HISTORIOGRAPHY
}

\begin{abstract}
Ideas about legal and constitutional systems in the British Isles, based upon a native genius, and ultimately upon the racial composition of the nation(s), were developed and deployed during the nineteenth century. The work of John Mitchell Kemble can be counted here amongst the developers of the literature informing this evolving historiographical norm of the Common Law tradition. Kemble's work was fundamental to the establishment of a historical theory which underlay the development of the Common Law and its institutions with a specific and conscious Germanic attribution and constructed derivation. Kemble's role was critical, in this creative discourse, as a polymath aggregator, whose work crossed modern-day conceptions of disciplinary boundaries. The developed and acquired Germanic historico-legal convention consistently emphasised a narrative of the Common Law's uniqueness, and it was a tradition which eventually gained a fundamental intellectual position.
\end{abstract}

Keywords: Legal History; Legal Theory; Historiography; Anglo-Saxon Laws; Methodology.

\section{INTRODUCTION}

Over the course of the nineteenth century, with the emergence of constitutional theory and legal history, certain ideas about legal and constitutional systems in the British Isles based upon a native genius, and ultimately upon the racial composition, of the nation(s) were developed and deployed - both by serious scholars and by polemicists. Put simply: the existence of an elemental Germanic constitution, carried as a birthright by Anglo-Saxon invaders and planted on British soil, and whose ancient roots firmly anchored the populace and the polity of the nation, was held to have ensured the development of a free and independent state which, over time, became the ideal-type of modern democratic governance. This ideal-type was to be contrasted, on the one hand from the autocratic centralisation of Roman-derived continentalism, and on the other hand from undirected and uncivilised Celticism of the wild and wet fringes. The work of John Mitchell Kemble, and then of Freeman, leading to that of Stubbs and Maitland, and so many others, can all be counted here amongst the developers of the literature informing the evolving historiographical norm

* Barrister and Solicitor. Dean of the College of Law and Justice, Victoria University, Melbourne, Australia, deanlawjustice@vu.edu.au. 
of the Common Law tradition (Maine 1861; Maine 1875; Maine 1883. On Maine, see Cocks 1988; Mantena 2010. A more recent and concise account in Lobban 2012, 4-13). This norm which Maitland ultimately designated "Die Germanische Rechtsgeschichte" (Fisher iii 1911, 457).

The acquired historico-legal conventions of the Common Law, as ostensibly revealed by the Coke-Hale-Blackstone rectilinear historiographical descent, congruently emphasised a narrative of the Common Law's unique growth and status. It was a pedigree which, by the mid nineteenth-century, had gained a primary intellectual position. Although (of course) its position was never simply axiomatic - the historiography of the Common Law was by degrees established as a dominant theory in a context of other competing theories which vied for acceptance. During the early part of the nineteenth century this particular historico-legal model had not yet so dominated the historico-legal epistemological environment so as to deprive alternative theories and approaches some space for development. For example, against the sere conventionality of this Common Law orthodoxy; of secure belief in an "ancient constitution" in the distant (AngloSaxon) past and the subsequent unbroken continuity of limited monarchy, parliament and the rule of the common law throughout England's history; there also stood competing schools of historical jurisprudence, including the historical school of Friedrich Carl von Savigny maintaining that law was the product of Volksgeist (Kantorowicz 1937; Haferkamp 2018), and (conversely) the antihistorical positivist school led by Jeremy Bentham and John Austin (Millon 1989, 669). Although Bentham was somewhat older, these scholars were John Mitchell Kemble's immediate contemporaries, and all offered possible alternatives to the ancient constitution of Common Law legend. This article seeks to demonstrate, accordingly, how the work of Kemble was fundamental to the establishment of a historical theory which underlay the development of the Common Law and its institutions with a specific and conscious Germanic provenance.

The article begins with a brief biography of John Mitchell Kemble, situating the man and his work, and then proceeds to consider Kemble's part in the development of a Germanic pedigree in British history, legal traditions and historiography. The initial focus is on Kemble's published work, and his public engagement with these intellectual cultures. There are then some questions which require further consideration, in relation to how we might make contact with Kemble's influence (or otherwise) on these legal, historical and academic cultures, from his unique, individual and arguably marginalized position. These questions afford the opportunity to look beyond Kemble's published works, into some archival materials, which will enable us to think through these issues more in the round. 


\section{JOHN MITCHELL KEMBLE: A BRIEF BIOGRAPHY ${ }^{1}$}

John Mitchell Kemble was born on the $2^{\text {nd }}$ of April, 1807 and was the eldest son of the actors Charles Kemble and Maria Theresa Kemble (nee De Camp or De Fleury). The Kemble family was a very famous thespian clan: the most famous of his near relatives were his uncle John Philip Kemble and his aunt Sarah Siddons, but a great many of his extended family were also celebrated actors. Kemble's sister, Fanny, who was also an actor, became in later life a prominent slavery abolitionist.

Kemble's initial schooling was with the lexicographer Charles Richardson, at his Clapham Common school, and it is possible that this early connection inspired in Kemble his passion for philology. From Clapham Kemble went to the grammar school at Bury St. Edmunds, and from there in 1826 he was admitted to Trinity College Cambridge. Among his friends at Cambridge was Alfred (later Lord) Tennyson. Although he apparently read much, and widely, Kemble apparently would not follow the prescribed curriculum and when he was sent up for examination in 1829 his degree was deferred pending further assessment. Kemble was also, around this time, admitted to the Inner Temple, however he evidently only studied those parts of the law which expounded legal history or ancient customs, and there is no evidence to indicate that he completed the Readings. Afterwards he travelled to Heidelberg and Munich, and it was during this trip to the Germanic states Kemble began to explore Teutonic philology.

On his return to England, and Cambridge, he graduated with the Bachelor of Arts in 1830, and later proceeded to Master of Arts in 1833, with the ostensible intention of taking holy orders. He was a member of the Apostles Club. Also at this time, 1830-31, Kemble joined a number of other young English gentlemen in the futile attempt to aid General Torrijos in his rebellion against the Spanish King Ferdinand VII; but in fact he travelled only as far as Gibraltar - and according to his sister Fanny he spent his time there "smoking, and drinking ale and holding forth on German metaphysics" (Kemble 1878, 62, 83. On Kemble see Lubenow 1998).

Abandoning his plans to take holy orders, in 1831 Kemble then travelled to Göttingen (and other places in Germany) to study under philologists, principally Jacob Grimm. His reputation as an Anglo-Saxon scholar was established by the publication of his edition of the poems of Beowulf in 1833, and this was reinforced in the following year by the delivery of a course of lectures on Anglo-Saxon language and literature at Cambridge. These lectures were, significantly, the subject of severe criticism in a pamphlet entitled The Anglo-Saxon Meteor: a Plea in Defence of Oxford, seemingly authored by Joseph Bosworth, on the basis that Kemble was unduly influenced by Danish

${ }^{1}$ Wiley 1971, 5-18; Burrow 1981, 162-163. 
and German scholarship. The criticism did not, however, appear to have had any destructive effect on Kemble's reputation. ${ }^{2}$

From 1835 to 1844 Kemble was the editor of the British and Foreign Review. In about 1836 he married Nathalie Auguste, daughter of Professor Amadeus Wendt of Göttingen, and after their marriage Kemble appears to have lived in London and worked at transcribing Anglo-Saxon charters in the British Museum and various collegiate and cathedral libraries. Much of this work was later published in his Codex Diplomaticus, which was published in six volumes between 1839 and 1848. By 1847 Kemble was working on his Saxons in England (published 1849); but after this time it appears that he spent most of his time in Germany, chiefly in Hanover where, in 1854, he was engaged to conduct archaeological investigations around Luneburg and to arrange and catalogue the collections in the Royal Museum.

Returning to England, he sent accounts of his discoveries in Germany to the Society of Antiquaries and to the Archaeological Institute, the sum of which was eventually published in 1857 with the title Horae Ferales, or Studies in the Archaeology of Northern Nations. Following this, the organising committee at the Art Treasures Exhibition at Manchester employed him to curate the collection of Celtic and Roman antiquities for them. In February 1857 he went on this business to Dublin, where he delivered an address on archaeology at the Royal Irish Academy. While in Dublin he apparently "over-exerted" himself, caught cold and died on the $26^{\text {th }}$ of March 1857.

The publication of Kemble's collection of documents belonging to the AngloSaxon period may be said to form the foundations of much of the knowledge of the ensuing centuries' scholarship of the institutions, laws and customs of the English before the Norman Conquest. In particular, Kemble's Codex Diplomaticus, containing over 1,400 documents, set a model for the future editors of charters and other ancient documents. It is conspicuous for its careful attention to detail, and (where applicable) its interpolation of critical commentary. Together with his Saxons in England, which despite its sometimes tendentious conclusions, was regarded as the finest source for pre-Norman material and commentary until the publication of Stubbs's Constitutional History in 1873.

In addition to the Codex, the Saxons in England and Horae Ferales, Kemble published another thirteen monographs, mostly covering Anglo-Saxon and antiquarian subjects. Kemble's other remaining published work is to be found in journals. He contributed to a wide range of periodicals, publishing approximately fifty discrete articles, although the bulk of his contributions are to be found in the Foreign Quarterly Review, the British and Foreign Review, Archaeologia, the Journal of the Royal Institute and Fraser's Magazine (See Dickins 1938, 31-36).

${ }^{2}$ See Gentleman's Magazine, new series, 1834, i 391 sqq; Gentleman's Magazine, new series, 1834, ii 483; Gentleman's Magazine, new series, 1835, i 43. 


\section{KEMBLE'S PART IN THE DEVELOPMENT OF A GERMANIC PEDIGREE IN BRITISH HISTORY, LEGAL CULTURES AND HISTORIOGRAPHY: THE PUBLISHED AND PUBLIC SIDE}

As we have noticed, the focus of Kemble's studies was directed towards the Anglo-Saxon period through the influence of Jacob Grimm, under whom he had first studied at Göttingen in 1831. Kemble's comprehensive knowledge of the Teutonic languages, and his critical proficiencies, were of course shown in his translation of the Anglo-Saxon poem of Beowulf (1833). Kemble's Codex diplomaticus aevi Saxonici (1839-1848), and his History of the Saxons in England (1849), then set out a new direction for English scholarship: one which was squarely oriented towards a Germanic pedigree in British history, culture and historiography. Kemble's historical world-view can be expressed thus: the kingdoms formed by the successor nations, including England, out of the Roman Empire, were connected with it by the adoption of many institutions, and monarchical authority based on these imperial rules underscored the advancement of the barbaric kingdoms; however in England it was the distinguishing legal institutions of the Germanic communities which prevented imperial traditions and customs from leading to absolutism. Underlying this critical and bivalent relationship was a racial grundnorm which situated a distinctively Teutonic Britain as the factual foundation of meaning and import.

As indicated, Kemble was a prolific writer, and almost as prolific a publisher. Reckoning on Dickins' bibliography (Dickins 1938, 31-36), he was the author of sixty-four discrete articles or monographs, some in multiple volumes, published between 1832 and 1863. The scope of the present discussion precludes a detailed examination of the full extent of these writings, and so it will be necessary, and it is hoped sufficient, to confine examination to some analysis of Kemble's two major oeuvres on Anglo-Saxon laws and institutions: the Codex Diplomaticus Aevi Saxonici and The Saxons in England.

The Codex Diplomaticus was, and remains to this day, the only thorough and wide-ranging collection of Anglo-Saxon charters, deeds, grants and other documents covering the entire period from the late seventh century until the Norman Conquest. Its arrangement is somewhat irregular, owing to the fact that as Kemble worked, on compilation, editing and commentary, new discoveries were made by him, and therefore included (out of order, or sequence, or taxonomy) as successive volumes - six over a period of nine years - were finalised and published. Indeed, in the preface to the sixth volume Kemble mentioned that he still had many charters still unprinted, and to the end of his life he hoped to publish an enlarged and corrected edition of the Codex. The scope of the work, encompassing more than 1,400 documentary artefacts, transcribed, plus commentary, the fastidious and at times painstaking attention to detail, and concreteness of philological exegesis mark out the Codex as a work of astonishing accomplishment, setting it 
apart from anything which had come before. It is, even so, possible to be critical of Kemble's methods and scholarship - and Maitland himself was one such critic in relation to Kemble's standard of editing of legal documents. All the same, Kemble claimed, entirely defensibly, that in his Codex:

"The extraordinary amount of information to be derived from these documents, renders their publication an era in the studies of Teutonic scholars; for law, language, and history, they are full of data, without which no enquiry in this field, however industrious and conscientious, could possibly be successful; ... though it belongs immediately to England, it contains many notices which will be valued both north and south of the Elbe.” (Kemble vi 1848, v)

and this was a declaration, in its general tenor, which Maitland did not dispute:

"to say at once that no one who has felt the difference between genius and industrious good intentions can ever differ with Kemble lightly or without regret. Kemble's work often requires correction; but if Kemble's work had not been, there would have been nothing to correct" (Pollock and Maitland 1898, 32)

As important, and certainly cutting-edge, as the Codex was - contemporaries most widely knew Kemble as the author of The Saxons in England. Indubitably written in a more accessible style than the Codex, this two volume work (still totalling near 1,100 pages) traversed the properties and aspects of Anglo-Saxon history and society rather than attempting to present a chronology or narrative of history. As such the work can be seen as thematic, its topics and divisions grouped around the significant legal institutions of land ownership, relationships, social hierarchies and economic power. It is, nonetheless, marked by the same rigour towards sources and scaffolded by Kemble's synthesis of historical, legal, literary and archaeological perspectives. So, more strongly and obviously than in the more methodological and technical Codex, Kemble's racial legal historiography, exemplified and encapsulated by the concept of volk, in The Saxons in England makes clear his thesis that the Anglo-Saxons were part of a collective Germanic culture and legacy, not as a separate race, but compelled by the evidence of the known historical and documented facts of European Germanic tribes evidencing how the ancestors of the English existed.

In addition to Kemble's published works, there is also a large body of unpublished papers, some mere fragments and brief notes, while others are virtually complete encyclopaedias, running to thousands of pages. We will turn, if ever so briefly, to these towards the conclusion of this article - if only to glimpse these peripheries of Kemble's thinking about some of the topics germane to this treatment of his historiographical significance.

Kemble was not, of course, the first English writer to appeal to Germanic antecedents. Why is it that John Mitchell Kemble, and not these earlier writers, is advanced here as the avant-gardist, given a tradition of English Germanism which was at least one hundred and fifty years established by the time of Kemble's arrival on the academic scene? It is because Kemble was really the first English scholar 
to eschew Tacitus as the initiator of Germanic tradition; and the first to examine, thoroughly and methodically, Anglo-Saxon sources from a self-consciously legal and historical perspective. Although it would be true to say that these earlier sources had, from time to time, been referenced by some of the less politicised writers, significantly Henry Spelman, Kemble brought his knowledge of the language to bear in a way which transformed English Germanism from a political gloss to a genuine historiography.

For at least one hundred and fifty years prior to Kemble's time there had been a tradition, in English, of appealing to a Germanic version of antiquity to create a lineage of respectable intellectual convention in history, the law and particularly politics. As Samuel Kliger has shown, in his now almost unnoticed The Goths In England (Kliger 1952. See also Kliger 1945), the seventeenth-century champions of parliamentary prerogative created a Gothic myth, for propaganda objectives, according to which the Goths appeared as heroic progressives and prototypical democrats of the ancient world. Beginning, typically, with Tacitus' Germania, writers such as Richard Verstegan whose Restitution of Decayed Intelligence (first published in 1605, and then republished four times up to 1673), firmly brought the English folk within the wider gens of a Germanic race and created a separate (and older, and thus more lawful) tradition to parvenu Royalist Normanism. Other early writers included some of the members of the so-called Society of Antiquaries, such as Francis Tate, John Dodderidge, William Camden, William Lambarde, Henry Spelman and Robert Cotton, whose collective works were first published (in part) in 1658, but which were written down and spoken in private conferences about fifty to seventy years earlier (Piggott 1967, 11-15. See also Stuckey 2012 and Stuckey 2006.). Kliger devotes a lengthy chapter to the originators of this Gothic apologue, placing especial emphasis on the role of Nathaniel Bacon, principally in his Historical and Political Discourse of the Laws and Government of England (1647), along with Thomas Hobbes and John Milton, as the chief intellectual polemicists of the parliamentary cause - every one, unfailingly and exclusively, referring back to the fons of Tacitus for the ancient, and thus precedential, "history" of Germanic democracy (Kliger 1952, 112-209).

Kliger's work foreshadowed that of Hugh MacDougall - his Racial Myth in English History: Trojans, Teutons and Anglo-Saxons, which was published in 1982, advanced the Germanic exegesis thesis of English historiography. With Kliger, MacDougall's presentation of an almost identical line of descent, from the classics to the politicised legalities of the seventeenth-century, traces the generated Teutonic viscera of Whig historiography: culminating, for MacDougall, with the publication by Sharon Turner of his History of the Anglo-Saxons in four volumes between 1799 and 1805, where "one can find all the ingredients necessary for an explicitly racist interpretation of English History" (MacDougall 1982, 96).

We shall return to this question of race shortly, however, one distinct topic raised by MacDougall, by way of demonstrating Kemble's representation of early 
Saxon forms of social and legal organisation is that of the Mark - ostensibly the sine qua non of elemental Teutonic landed and legal social bonding. MacDougall notes, relevantly, that Kemble's treatment of the Mark was derived more from philological abstraction than from tangible evidence - and the criticism (on this topic, at least) is justified. Equally justified, however, is the fact that despite evident weaknesses on this topic, Kemble's thesis was, as we shall see, adopted and propagated by the likes of Freeman and Stubbs (MacDougall 1982, 96).

Turning the frame of reference from the origins of authority to the place of language, Clare Simmons' Reversing the Conquest, published in 1990, completes a portrayal of Kemble's antecedents with a focus on how the control of the written vestiges of culture was turned to historiographical command of a present, and enduring, discourse. Simmons, correctly, discounts the significance of Sharon Turner, on the basis that he had no interests in the Saxons outside of England and did not utilise Germanic literary source materials, and she gives precedence to that of Kemble, and (to a lesser degree) that of Benjamin Thorpe. The assessment and evaluation is apposite, and insofar as the work of Thorpe (1782-1870) is relevant for our purposes here, it needs to be admitted that his very fine scholarship was neither focused on any explicitly legal historiographies nor on any specifically Germanic tradition - his work being dedicated to Scandinavian and linguistic heredities. Nor can it be said, as Simmons readily acknowledges, that Thorpe's works, which were very poor sellers, had any really significant impact on wider or longitudinal intellectual consciousness (Simmons 1990, 16-19, 49 and 66-70).

Kemble thus established a racial archetype, solidly supported by attentive documentary scholarship, as well as archaeological data (Williams 2006) ${ }^{3}$, which was assumed and amplified by others over the course of the latter part of the nineteenth century. Its chief proponent, and it is not too extravagant even to say polemicist, was A.E. Freeman (1823-1892): the famous English historian, and Liberal politician. He held the position of Regius Professor of Modern History at Oxford from 1884, and published 239 distinct works, perhaps the best known being History of the Norman Conquest (published 1867-1876). However, while Kemble certainly regarded the peoples subdued by the Germanic tribes as 'degenerate races' (Kemble 1876, 232), Freeman's racial essentialism was, by contrast to that of Kemble's, even more developed, specific and all-embracing. As 'an ardent

\footnotetext{
3 "It has often been implicitly assumed that nineteenth-century antiquarians and archaeologists constructed their interpretations in a theory-free environment because of their focus upon the description and illustration of objects and sites. In contrast with the speculations of eighteenthcentury antiquaries, mid nineteenth-century archaeologists emphasised their reliance on facts and the scientific nature of their discipline. This is illustrated by Kemble's efforts to contrast his own 'rational' interpretation to those made by 'curiosity hunters' of earlier centuries who failed to adequately record their excavations and finds ... Kemble explicitly warned his archaeological colleagues to refrain from theorising ... Yet as we have argued, historical and philological theories inspired Kemble's archaeology." (Williams 2006, 7).
} 
Teutonist' Freeman can be seen as having cultivated his antipathy toward the non-Aryan, and even towards non-Germanic Aryans such as the Celts. Kemble's theory of laws, institutions and government certainly sprang from his theory of race, but it is apparent, for example, that his representation was in some respects idealised rather than entirely empirical and that, for instance, Kemble's handling of the Mark as a material economy was particularly abstracted (Dewey 1972, 301-302 ${ }^{4}$ ).

These traits, nonetheless, exemplify the distinctive qualities of Kemble's legal history: not only in his broad view about the compelling inspiration of the Germanic idea as an archetype of exceptionality; but also in his method and practice as an historian of legal forms. This premise sets Kemble, foreshadowing Freeman (Freeman 1872, 40. This essay was first published in 1860) and ultimately Powicke (Powicke 1931, 15 and 23. See also Prestwich 1963, 41-43), and so many others, and in the almost dynastic sense prefigured by Levine, as the innovative and prototypical English proponent of insular uniqueness over continental uniformity, of national progress over transnational fusion (Pocock 1987, 385; Levine 1986, 10-11 and 77ff. See also Hollister 1961, 642ff; Melman 1991, 578-584; McClelland 1971, 43-44 and 102). Burrow's seminal Liberal Descent devotes an entire chapter to 'The Germanic Inheritance', and there Kemble's work is singled out as the "watershed" - with Kemble as the innovator both in terms of Germanic hypothesis and applied method. In Burrow's account it was Kemble who made the break from the earlier (late eighteenth-century) "self-congratulatory racialist historiography" which was "fanciful and ephemeral" to a more serious, research-based scholarship of documentary analysis (Burrow 1981, 116 and 120).

However simply because the debt, in establishing the framework for the exclusivity theory of English history to be fashioned into advanced histories, which was owed by future historians to Kemble can be recognised, it is important to not fall into the very kind of anachronism and teleology for which Whig history is often criticized. In Blaas' adroit treatment of the ideas and conflicts within Victorian historiography, Continuity and Anachronism, this tension is specifically considered. Furthermore, Blaas portrays, as the key to this essential characteristic of historiographical anachronism and teleology, the determined political preoccupation of Freeman as campaigning intellectual polemicist (Blaas 1978, 90-100 and 109-110. Cf. Collini, Winch, Burrow 1983, 186-188). More

${ }^{4}$ As detailed by Dewey: "The building-blocks of Kemble's Saxon society were the village communities; the basic units in a hierarchic political federation. Existing families threw out fresh households within the community; existing villages threw out fresh villages within the waste; and the process was repeated until the family became a tribe, and the tribe a kingdom." (Dewey 1972, 301-302; Dewey cites Kemble 1849, 5-6 and 39-40). Dewey also cites, interestingly, Francis Palgrave (Palgrave 1867) although Dewey does not cite a specific page reference to Palgrave at this point or indeed expand upon the noted connection (See also, on this specific point, Burrow 1988, 64-69). 
precisely however, but nonetheless consistent with the estimation of Blaas, it is critical to acknowledge that Kemble's influence on the larger figures of Stubbs, Freeman and Maitland needs to be characterised as more intricate and nuanced - as Blaas demonstrates with exegetic deftness (Blaas 1978, 154-157 and 161-171; Stubbs 1883, 187-188; Freeman 1872, 272-273; Pollock, Maitland 1898. See also Frantzen, Niles 1997).

Certainly, in the second half of the nineteenth century, and extending into the early years of the twentieth, two remarkable Professors dominated the scholarship of English medieval history. As Campbell explains, William Stubbs and his younger contemporary Frederic William Maitland were, respectively, the establisher of medieval history as a subject for study in British universities, and the extraordinary historian of English law. Both owed much to German historiography, and their commitment was part of an Anglo-German intellectual affiliation in the study and appreciation of history. Although this relationship was wrecked by the First World War, and the underpinning theory (insofar as it related to and depended upon the Teutonic origins of representative government) was publically debunked by Beard (Beard 1932; Fleming 1997), the legacy and tradition of Anglo-Germanism generally, and Anglo-German legal historiography specifically - with its origins in Grimm and Kemble, settled by Stubbs and Maitland, and upheld by disciples such as Tanner, Powell, Tait, Tout, Powicke, Trevelyan and Milsom - remained strong enough to organize much of the intellectual paradigm of constitutional history and associated historico-legal discourse throughout the twentieth century (Campbell 2000. See also Bentley 2005. On Maitland, in particular, see Maitland 1897, 365 and Fisher ii 1911, 313-365. See also Hudson 2007. On Stubbs, see Stubbs 1883, i and 2-3. Similarly, Vinogradoff 1893 and Vinogradoff 1905, 25-27). It is a perspective, unsurprisingly, not at all lost on Welsh scholars (Dawkins 1882; Williams 2014; Davies 1979, 14-24; and more prosaically, for example, Dawkins 1889, 6). Lobban's 2012 survey of this historiography of the Common Law, although differing on the position of Freeman vis-à-vis "Germanic method", nonetheless corroborates this solid genealogy of English legal history since the late nineteenth century (Lobban 2012, 4-13).

\section{KEMBLE'S PART IN THE DEVELOPMENT OF A GERMANIC PEDIGREE IN BRITISH HISTORY, LEGAL CULTURES AND HISTORIOGRAPY: THE UNPUBLISHED AND PRIVATE SIDE}

John Mitchell Kemble did not live to a great age, nor was it his fortune to fully develop and realise many of the projects which he commenced and which might have extended his extant works into a more mature and worked-through corpus of legal and historical scholarship. His death, at age 49 in 1857, cut short a career which had not always met with institutional recognition. He was never successful 
in obtaining a permanent academic post, and in this sense it is fair to consider him as an outsider to the traditional academic establishment. In terms of how the lack of sinecure affected his publishing, also, Kemble's livelihood depended to a certain degree upon paid employment, for example: as the editor of the British and Foreign Review from 1835 to 1844; from 1840 to his death Kemble was examiner of plays, which carried a small stipend; and from commissioned work, such as his State Papers and Correspondence Illustrative of the Social and Political State of Europe from the Revolution to the Accession of the House of Hanover (1857).

Aside from the sixty-four distinct articles and monographs published by Kemble, there exists a quite substantial body of his unpublished materials, now dispersed. The Kemble papers are scattered in various locations, mostly in research libraries located in the United Kingdom and the USA. Professor Simon Keynes, at Trinity College in Cambridge, has catalogued the whereabouts of all known Kemble manuscripts. ${ }^{5}$ The majority of these MSS are letters, fragments and short notes; however there is also a fairly significant number of items which represent preparatory and draft work of some considerable detail and development. Again, constrained by the scope of the present commentary, it is possible to highlight only a small selection of these artefacts, for germane demonstrative purposes; however some of Kemble's letters are, in fact, very important in evidencing his German source materials, emphases and influences. ${ }^{6}$

Possibly more important amongst Kemble's unpublished papers, from the perspective of this article ${ }^{7}$, are six volumes held by the Library of Congress in Washington DC. ${ }^{8}$ These volumes include three volumes which are notebooks from Kemble's time at Cambridge as an undergraduate, from about 1827, and demonstrate his early thinking about Anglo-Saxonism, and his first contacts with German scholarship. Then, in two volumes which are entitled "AngloSaxon Notebook", both of which appear to date from about 1832, we can see the development of this Germanic scholarship. And then, most significantly, the sixth item (dated 1832-1833) is a very major volume entitled "Collections for the Early Law of England", which runs to 931 folios, representing the draft of an encyclopaedic work which was never realised or completed. In it Kemble is very conscious of this work improving and correcting earlier writers: he forgives Spelman, Coke, Selden and Somner (because they had limited access

\footnotetext{
${ }^{5} \mathrm{http}: / /$ www.kemble.asnc.cam.ac.uk.

${ }^{6}$ Particularly those at Oxford, Bodleian Library MS Eng. lett. B. 4 (Fols. 68-79), Cambridge University Library MS Add. 7652 II CC / 32 and British Library BL Add. MS 36531 and BL Add. MS 52184 fols. 194b and 204b.

${ }^{7}$ Excepted here, but worthy of note, is his now famous, possibly even infamous "Gibraltar Diary" held at the Pierpont Morgan Library, New York City, reference MA 3321.

${ }^{8}$ LAW MSS 8-13.

${ }^{9}$ LAW MS 12.
} 
to manuscript sources); but he does not likewise forgive Palgrave and Turner. ${ }^{10}$ The overall organisation is by named topic - usually separated by some blank pages - so obviously Kemble set it out, with space between each topic so he could add more detail later. Sometimes this is evident, with a different ink and style. Other times there are just short entries, then many blank pages (when he did not come back with more). There are a few instances of just a heading, then nothing but blanks. The work is replete with references to German scholarship and original research. $^{11}$

To this compendium we can also relevantly add a number of Kemble's annotated collections, such as two held by Cambridge University Library ${ }^{12}$, and Kemble's holograph annotations on his own copy of Codex Diplomaticus, held at British Library ${ }^{13}$. Kemble's unpublished review of Jakob Grimm's Deutsche Grammatik is similarly of evidential value, showing this intellectual commitment. ${ }^{14}$ Lastly, it is important to notice from the point of view of race theory, Kemble's so-called "Races of Europe" essay ${ }^{15}$, and particularly the part entitled "The Kelts and Germans" (Kemble's own title) - its more detailed racial theory / history / archaeology, setting out Kemble's self-conscious way of doing historical method. It is heavily footnoted and referenced - a nearly finished draft, almost ready for submission for a publication which never eventuated. More clearly, and more directly, than in published references, Kemble's reliance on, and elaboration of, German sources and research, is strongly evident in these, and many other, unpublished manuscript sources.

\section{CONCLUSION}

This article has argued ideas about legal and constitutional systems in the British Isles, based upon a native genius, and ultimately upon the racial composition of the nation(s), were developed and deployed during the nineteenth century and that the existence of an elemental Germanic constitution, and whose ancient roots firmly anchored the populace and the polity of the nation, was held to have ensured the development of a free and independent state as the ideal-type of modern democratic governance. The work of John Mitchell Kemble, and many

${ }^{10}$ LAW MS 8-9.
${ }^{11}$ For example, and relevantly to our discussion, in relation to the "Mark" LAW MS 441.
${ }^{12}$ Cambridge University Library, GG. 5. 35 and Tracts MS. Ii. 1. 33.
${ }^{13}$ BL Add. MS 32126 - BL Add. MS 32131. in 1981 (Wiley 1981).

${ }^{15}$ Amongst the loose papers held at the Rubenstein Library (Special Collections) at Duke University (North Carolina), in the fourth folder of the loose papers constituting the "John Mitchell Kemble Papers, 1829-1857". 
others, can all be counted here amongst the developers of the literature informing the evolving historiographical norm of the Common Law tradition. Kemble's role was critical, as an innovator, in this creative discourse, not just as an historian, or a linguist, but really as a polymath aggregator, whose work crossed modernday conceptions of disciplinary boundaries. It is worth citing the recent work of Howard Williams on this point:

“...the archaeological interpretations and practices of John Mitchell Kemble were influenced by his philological and historical writings in a variety of ways. He was not simply describing his discoveries in an empirical or objective manner, but constructing a theoretical interpretation drawing on a range of sources from his wide ranging studies of northern European societies with an explicit Germanist and Anglo-Saxonist ideological programme in mind. Heathen graves were used as a metaphor for Anglo-Saxon racial and socio-cultural status set against a background of origins in northern Germany. ... by comparing Kelts and Saxon in terms of successive phrases [sic] or invasions, he seems to implicitly assert the superiority of the latter over the former. ... Kemble's use of archaeological evidence was not simply a response to his existing beliefs and ideas gained from his other studies. His archaeological practice and theory reflects the use of material culture and cemeteries as a powerful metaphorical representation of a clustering of racial and philological values that Kemble believed reflected the primitive, pagan, noble Teuton. By turning to archaeology, Kemble was providing the origin myth of the Anglo-Saxons with new historical legitimacy and a physical component." (Williams 2006, 11. See more generally Kohl, Fawcett 1995; Brooks 1998)

The developed and acquired Germanic historico-legal convention consistently emphasised a narrative of the Common Law's uniqueness, and it was a tradition which eventually gained a fundamental intellectual position. This article has sought to demonstrate, accordingly, how the work of Kemble (both published, and unpublished) was fundamental to the establishment of a historical theory which underlay the development of the Common Law and its institutions with a specific and conscious Germanic attribution and constructed derivation.

\section{BIBLIOGRAPHY}

Beard, Charles A. 1932. "The Teutonic Origins of Representative Government." The American Political Science Review 26 (1): 28-44.

Bentley, Michael. 2005. England's Past: English Historiography in the Age of Modernism, 18701970. Cambridge: Cambridge University Press.

Blaas, Petrus B.M. 1978. Continuity and Anachronism: Parliamentary and Constitutional Development in Whig Historiography and in the Anti-Whig Reaction Between 1890 and 1930. The Hague and Boston: Martinus Nijhoff.

Brooks, Chris. 1998. "Introduction: Historicism and the Nineteenth Century". In The Study of the Past in the Victorian Age. Edited by Vanessa Brand. 1-20. Oxford: Oxbow Books.

Burrow, John W. 1981. A Liberal Descent: Victorian Historians and the English Past. Cambridge: Cambridge University Press.

Burrow, John W. 1988. Whigs and Liberals: Continuity and Change in English Political Thought. New York: Clarendon Press. 
Campbell, James. 2000. "Stubbs, Maitland, and Constitutional History". In British and German Historiography, 1750-1950: Traditions, Perceptions and Transfers. Edited by Benedikt Stuchtey, Peter Wende. 99-122. Oxford: Oxford University Press.

Cocks, Raymond C.J. 1988. Sir Henry Maine: A Study in Victorian Jurisprudence. Cambridge: Cambridge University Press.

Collini, Stefan. Donald Winch. John Burrow. 1983. That Noble Science of Politics: A Study in Nineteenth-Century Intellectual History. Cambridge: Cambridge University Press.

Davies, R.R. 1979. Historical Perception: Celts and Saxons. Inaugural Lecture delivered at the University College of Wales, Aberystwyth (22 $2^{\text {nd }}$ of November, 1978). Cardiff: University of Wales Press.

Dawkins, William B. 1882. "The Ancient Ethnology of Wales". Y Cymmrodor 5: 209-223.

Dawkins, William B. 1889. The Place of the Welsh in the History of Britain. London: Simpkin Marshall.

Dewey, Clive. 1972. "Images of the Village Community: A Study in Anglo-Saxon Ideology". Modern Asian Studies 6 (3): 291-328.

Dickins, Bruce. 1938. J.M. Kemble and Old English Scholarship. The Sir Israel Gollancz Memorial Lecture. London: The British Academy, 1938.

Fisher, H.A.L. 1911. The Collected Papers of Frederic William Maitland. Vol. i-iii. Cambridge: Cambridge University Press.

Fleming, R. 1997. "Henry Adams and the Anglo-Saxons". In The Preservation and Transmission of Anglo-Saxon Culture. Edited by Paul E. Szarmarch, Joel T. Rosenthal. 13-36. Michigan: Western Michigan University.

Frantzen, Allan J. John D. Niles. Eds. 1997. Anglo-Saxonism and the Construction of Social Identity. Gainsville: University of Florida Press.

Freeman, Edward A. 1872. "The Continuity of English History". In Historical Essays. $2^{\text {nd }}$ ed. London: Macmillan.

Gentleman's Magazine. New Series, i. 1834: 391-393.

Gentleman's Magazine. New Series, ii. 1834: 483-486.

Gentleman's Magazine. New Series, i. 1835: 42-44.

Haferkamp, Hans Peter. 2018. Die Historische Rechtsschul. Frankfurt: Klostermann.

Hollister, C. Warren. 1961. "The Norman Conquest and the Genesis of English Feudalism". The American Historical Review 66 (3): 641-663.

Hudson, John. 2007. F. W. Maitland and the Englishness of English Law. London: Selden Society.

Kantorowicz, Hermann. 1937. "Savigny and the Historical School of Law". Law Quarterly Review 53: 326-343.

Kemble, Fanny. 1878. Record of a Girlhood. London: R. Bentley \& Son.

Kemble, John Mitchell. 1848. Codex Diplomaticus Aevi Saxonici. Vol. vi. Cambridge: Cambridge University Press.

Kemble, John Mitchell.1849. The Saxons in England. $1^{\text {st }}$ ed. Vol. 2. London: Longman.

Kemble, John Mitchell. 1876. The Saxons in England. $2^{\text {nd }}$ ed. Vol. 1. London: Longman.

Kliger, Samuel. 1945. "The Goths in England: An Introduction to the Gothic Vogue in EighteenthCentury Aesthetic Discussion”. Modern Philology 43 (2): 107-117

Kliger, Samuel. 1952. The Goths in England: A Study in Seventeenth and Eighteenth Century Thought. Cambridge, MA: Harvard University Press.

Kohl, Philip L. Clare P. Fawcatt. Eds. 1995. Nationalism, Politics and the Practice of Archaeology. Cambridge: Cambridge University Press.

Levine, Philippa. 1986. The Amateur and the Professional: Antiquarians, Historians and Archeologists in Victorian England, 1838-1886. Cambridge: Cambridge University Press. 
Lobban, Michael. 2012. "The Varieties of Legal History”. Clio@Themis 5: 1-29.

Lubenow, William C. 1998. The Cambridge Apostles: 1820-1914. Cambridge: Cambridge University Press.

MacDougall, Hugh A. 1982. Racial Myth in English History: Trojans, Teutons and Anglo-Saxons. Montreal: Harvest.

Maine, Henry James Summer. 1861. Ancient Law: Its Convention with the Early History of Society and its Relation to Modern Ideas. London: John Murray.

Maine, Henry James Summer. 1875. Effects of Observation of India on Modern European Thought. The Rede Lecture, delivered before the University of Cambridge, May 22, 1875. London: John Murray.

Maine, Henry James Summer. 1883. Dissertation on Early Law and Customs. New York: Henry Holt.

Maitland, Frederic William. 1897. Domesday Book and Beyond: Three Essays in the Early History of England. Cambridge: Cambridge University Press.

Mantena, Karuna. 2010. Alibis of Empire: Henry Maine and the Ends of Liberal Imperialism. Princeton: Princeton University Press.

McClelland, Charles E. 1971. The German Historians and England: A Study in Nineteenth-Century Views. Cambridge: Cambridge University Press.

Melman, Billie. 1991. "Claiming the Nation's Past: The Invention of an Anglo-Saxon Tradition". Journal of Contemporary History 26: 575-595.

Millon, David K. 1989. "Positivism in the Historiography of the Common Law". Wisconsin Law Review: 669-714.

Palgrave, Francis. 1867. History of the Anglo-Saxons. New ed. London: William Tegg.

Piggott, Stuart. 1967. Celts, Saxons and the Early Antiquaries: The O'Donnell Lecture 1966. Edinburgh: Edinburgh University Press.

Pocock, John G.A. 1987. The Ancient Constitution and the Feudal Law - A Study of English Historical Thought in the Seventeenth Century: A Reissue with a Retrospect. Cambridge: University Press.

Pollock, Frederick. Frederic William Maitland. 1898. A History of English Law. $2^{\text {nd }}$ ed. Cambridge: Cambridge University Press.

Powicke, Maurice. 1931. Medieval England, 1066-1485. London: Oxford University Press.

Prestwich, John O. 1963. "Anglo-Norman Feudalism and the Problem of Continuity". Past and Present 26: 39-57.

Simmons, Clare A. 1900. Reversing the Conquest: History and Myth in 19 1 th $^{\text {-Century }}$ British Literature. New Brunswick: Rutgers University Press.

Stubbs, William. 1883. The Constitutional History of England. Oxford: Clarendon Press.

Stuckey, Michael. 2006. “...this Society tendeth...” Elite Prosopography in Elizabethan Legal History". Prosopon 1: 1-58.

Stuckey, Michael. 2012. "Late Sixteenth and Early Seventeenth Century English Humanism and Antiquarianism: The Prosopographical Method and Reflections on Historico-Legal Tradition". Journal of Legal History 33 (1): 31-64.

Vinogradoff, Paul. 1893. "Folkland". The English Historical Review 8: 1-17.

Vinogradoff, Paul. 1905. The Growth of the Manor. London: Allen \& Unwin.

Wiley, Raymond A. 1971. John Mitchell Kemble and Jakob Grimm: A Correspondence, 1832-1852. Leiden: Brill.

Wiley, Raymond A., ed. 1981. “John Mitchell Kemble's Review of Jakob Grimm's Deutsche Grammatik". Old English Newsletter Subsidia 6. 
Williams, Emyr W. 2014. "JE Lloyd and the Intellectual Foundations of Welsh History". The National Library of Wales Journal 36 (1): 54-97.

Williams, Howard. 2006. "Heathen Graves and Victorian Anglo-Saxonism: Assessing the Work of John Mitchell Kemble". Anglo-Saxon Studies in Archaeology and History 13: 1-18.

\section{Michael Stuckey}

\section{ANGLO-GERMAŃSKA HISTORIOGRAFIA PRAWNICZA JOHNA MITCHELLA KEMBLE'A}

Streszczenie. W dziewiętnastym stuleciu doszło do rozwoju i rozprzestrzenienia się różnych koncepcji dotyczących porządków prawnych i ustrojowych Wysp Brytyjskich, które wywodziły się z ducha narodowego, a ostatecznie opierały się na rasowej kompozycji narodu (bądź narodów). John Mitchell Kemble może być zaliczony w poczet twórców literatury prezentującej ten ewolucyjny wzorzec tradycji common law. Działalność Kemble'a była kluczowa dla ustanowienia doktryny historycznej, która leży u podstaw rozwoju common law oraz jego instytucji, ze szczególnym i świadomym uwzględnieniem germańskich oraz pochodnych wpływów. Pozycja Kemble’a była ważna, w trakcie twórczego dyskursu, jako erudycyjnego zwornika, którego działania wykraczały poza współczesną koncepcję ograniczonych dyscyplin naukowych. Rozwinięta i przyjęta germańska konwencja historyczno-prawna konsekwentnie kładła nacisk na narrację dotyczącą wyjątkowości common law. Była to również tradycja, która ostatecznie zyskała fundamentalne znaczenie dla nauki.

Slowa kluczowe: historia prawa; teoria prawa; historiografia; prawa anglosaskie; metodologia. 